\title{
Constraining the magnetic properties of ultrafine- and fine-grained biogenic magnetite
}

Tongwei Zhang ${ }^{1,2}$ and Yongxin Pan ${ }^{1,2,3^{*}}$

\begin{abstract}
Four samples containing ultrafine- and fine-grained magnetite of magnetoferritins and magnetotactic bacteria cells were magnetically characterized at both room and low temperatures. Transmission electron microscopy analysis showed that the biometrically synthesized magnetoferritins (M-HFn) have magnetite cores with a mean size of $5.3 \pm 1.2 \mathrm{~nm}$ inside protein shells, while Magnetospirillum gryphiswaldense MSR-1 cell produced intracellular magnetosome magnetites have a mean size of $29.6 \pm 7.6 \mathrm{~nm}$, arranged in a single chain. A pure M-HFn sample $\left(M_{1}\right)$, MSR-1 whole cell sample $\left(M_{4}\right)$ and two samples $\left(M_{2}, M_{3}\right)$ mixing M-HFn with MSR-1 whole cells in different weight percentages were measured, including hysteresis, temperature dependency of magnetization and remanence and frequency dependence of AC susceptibility at low temperature. At room temperature, the ultrafine-grained magnetite core of $\mathrm{M}-\mathrm{HFn}$ of $\mathrm{M}_{1}$ sample has a typical superparamagnetic (SP) behavior. The chain-arranged magnetosome magnetite of MSR-1 cells of $\mathrm{M}_{4}$ sample shows a stable single-domain (SD) state. At low temperature, the $\mathrm{M}_{2}$ sample with $16 \mathrm{wt} \%$ SD magnetosome magnetite and the $\mathrm{M}_{3}$ sample with $43 \mathrm{wt} \% \mathrm{SD}$ magnetosome magnetite behave somewhat similar to the $\mathrm{M}_{1}$ (pure M-HFn), due to the SP component from M-HFn magnetite. With the dominance of SP magnetite in samples $M_{1}, M_{2}$, and $M_{3}$, the coercivity and saturation remanence decrease significantly as temperature increasing from 5 to $20 \mathrm{~K}$. Of note, the magnetization and frequency dependence of AC susceptibility at low temperature are sensitive to SP magnetites in measured samples. The magnetosome magnetite produced by MSR-1 has a Verwey transition temperature at around $100 \mathrm{~K}$, which is consistent with previous observations on magnetotactic bacteria. This study provides useful clues for identification of SP and SD magnetite in sediments, as well as related potential biomedical and biomagnetic applications.
\end{abstract}

Keywords: Superparamagnetism (SP), Magnetoferritins, Magnetosome magnetite, Low-temperature measurements, Biogenic magnetite

\section{Introduction}

Superparamagnetic (SP) magnetite has been found in numerous geological samples, e.g., soils, pelagic sediments, tuffs and ice sheets, usually with some distinct magnetic properties; therefore, they are of great interests in rock magnetism, environmental magnetism and paleomagnetism. While progress has been made in identifying

\footnotetext{
*Correspondence: yxpan@mail.iggcas.ac.cn

${ }^{1}$ Biogeomagnetism Group, Key Laboratory of Earth and Planetary Physics, Institute of Geology and Geophysics, Institutions of Earth Science,

Chinese Academy of Sciences, Beijing, China

Full list of author information is available at the end of the article
}

the SP magnetite in nature samples (Bedanta and Kleemann 2009; Creer 1961; Dunlop 1973; Lanci and Kent 2006; Liu et al. 2010; Maher 2016; Oldfield et al. 1981; Smirnov and Tarduno 2001; Tarduno 1995; Tauxe and Wu 1990; van de Moortele et al. 2007; Worm and Jackson 1999), some ambiguities in measurement interpretation remain, partially because of uncertainties in size distribution and particle magnetostatic interaction.

Worm and Jackson (1999) studied the magnetite in the Yucca Mountain tuff samples through measurement of hysteresis loops, isothermal remanent magnetization acquisition, thermal demagnetization and frequency and temperature dependence of susceptibility. They noted 
deviations exist between modeled and measured susceptibility, which was associated with size-dependent anisotropy, non-uniform magnetization and also uncertainties in the pre-exponential time (Worm and Jackson 1999). The pre-exponential time of magnetite was thought to be size-dependent and sensitive to particle interaction (Cao et al. 2010; Moskowitz et al. 1997).

Although SP magnetite grains are unable to retain a remanence at room temperature, numerical simulations and experimental measurements indicate that SP magnetite in sediments is abundant evidenced by their contribution to hysteresis loops (Tauxe et al. 1996). Their presence is indicative of magnetite reduction diagenesis at the Fe-redox boundary in pelagic sediments (Roberts et al. 2013; Tarduno 1995) and can reflect climate-associated pedogenesis in loess and soils (Maher 2016).

Stoichiometric SP magnetite with very narrow size distribution and good biocompatibility is also of great interest in magnetic nanomaterial production and related medical applications, e.g., contrast agents of magnetic resonance imaging (Bonnemain 1998; Hergt et al. 1998; Roch et al. 1999; Thorat et al. 2016; Tromsdorf et al. 2007; Wang et al. 2001), hyperthermia treatments of tumors (Hergt et al. 2008; Jordan et al. 1999), biomedical application (Fan et al. 2012; Gao et al. 2017; Schaefer et al. 2007; Thorek et al. 2006) and nanometric biomaterials (Amstad et al. 2011; Cao et al. 2014; Zhang et al. 2017).

Ferritin is a widely existing iron-storage protein in many living organisms throughout animals, plants and bacterias. It is a cage-like protein with an external diameter of $12 \mathrm{~nm}$ and an inner diameter of $8 \mathrm{~nm}$, an ideal versatile platform for synthesis of size-controllable nanometer-scale ferrimagnetic particles. The structure of mature mammalian ferritin consists of a 24-subunit protein, composed of heavy subunits $(\mathrm{H})$ and light subunits (L). Cao et al. (2010) used the recombinant human $\mathrm{H}$-chain ferritin (HFn) and successfully synthesized mono-dispersed, non-interacting ferrimagnetic magnetoferritin (M-HFn) nanoparticles, which have magnetite cores with average diameters of a few nanometers (Cai et al. 2015; Cao et al. 2010). These biomimetic synthesized ferrimagnetic cores have extremely narrow size distribution and high crystallinity, are superparamagnetic at ambient temperature and due to their intact protein shell separation, have nearly no magnetostatic interactions (Cao et al. 2010; Walls et al. 2013).

Magnetotactic bacteria (MTB) intracellularly produce nanosized single-domain $(\mathrm{SD})$ magnetite magnetosomes (30-120 nm), usually arranged in chains, allowing the microbes orientate in the ambient magnetic field (Blakemore 1975; Bazylinski and Frankel 2004), which is a model microorganism for biogeomagnetism study. MTB play important roles in sedimentary magnetism and iron cycling and have application in paleoenvironmental studies (Lin et al. 2014). Over the past decades, MTB have been found in a diverse range of aquatic environments, such as freshwater lakes, rivers, ponds, estuaries, lagoons, mangrove swamps, intertidal zones, deep-sea sediments, marine oxygen minimum zones, saline-alkaline lakes and hot springs, and appear to be important in the geochemical cycling of Fe, S, N and C and so forth (Bazylinski and Frankel 2004; Faivre and Schuler 2008; Kirschvink 1980; Kopp and Kirschvink 2008; Lin et al. 2014; Pan et al. 2005a; Schuler and Frankel 1999; Simmons and Edwards 2007; Zhou et al. 2012). Fossil magnetosomes (magnetofossils) have been widely identified in numerous of sediments, and they are important magnetic carriers (Chang et al. 2014; Channell et al. 2013a, b; Kopp et al. 2007; Li et al. 2013; Liu et al. 2015; Mao et al. 2014; Moskowitz et al. 1993, 2008; Pan et al. 2005b; Petersen et al. 1986; Yamazaki and Shimono 2012; Zhao et al. 2016).

In this study, we characterized the ultrafine-grained magnetite of M-HFn and fine-grained SD magnetosome magnetite by both room- and low- temperature magnetic measurements. The magnetoferritin, Magnetospirillum gryphiswaldense MSR-1 whole cells and two mixed samples with different concentrations of magnetoferritins were analyzed. The objective of this study is to examine magnetic properties of these two types of biogenic magnetites, in particular the traits of ultrafine-grained superparamagnetic magnetite. Applications of ultrafine- and fine-grained magnetite in rock magnetism, biomagnetic and biomedicine are also discussed.

\section{Materials and methods}

\section{Preparation of samples}

The M-HFn nanoparticles were synthesized by the recombinant ferritin cage using the method of Cao et al. (2010) with minor modifications. Fe(II) $(25 \mathrm{mM}$ $\left.\left(\mathrm{NH}_{4}\right)_{2} \mathrm{Fe}\left(\mathrm{SO}_{4}\right)_{2} \cdot 6 \mathrm{H}_{2} \mathrm{O}\right)$ was added in a rate of $80 \mathrm{Fe} /$ protein/minute. Simultaneously, freshly prepared $\mathrm{H}_{2} \mathrm{O}_{2}$ $(8.33 \mathrm{mM})$ was added as an oxidant in accordance with stoichiometric equivalents $\left(1: 3, \mathrm{H}_{2} \mathrm{O}_{2} / \mathrm{Fe}^{2+}\right)$. Then a theoretical 7000 atoms of Fe per protein cage was added to the reaction vessel and allowed to react for another $10 \mathrm{~min}$. Then, $200 \mu \mathrm{l}$ of $300 \mathrm{mM}$ sodium citrate was added to each sample to chelate any free metal ions. Finally, purification was performed through size exclusion chromatography (Sepharose 6B, GE Healthcare) after centrifugation at $10,000 \mathrm{rpm}$ for $30 \mathrm{~min}$ at $4{ }^{\circ} \mathrm{C}$.

Magnetospirillum gryphiswaldense strain MSR-1 was cultured in a sodium lactate medium (SLM) at $30{ }^{\circ} \mathrm{C}$ while spinning at $100 \mathrm{rpm}$ (Ding et al. 2010; Jogler and Schuler 2009); sterile ferric citrate was added as iron source. Fresh whole cells were collected by centrifugation at $8000 \mathrm{rpm}$ for $10 \mathrm{~min}$ at $4{ }^{\circ} \mathrm{C}$ after culturing for $24 \mathrm{~h}$. 
In this study, four samples $\left(M_{1}, M_{2}, M_{3}\right.$ and $\left.M_{4}\right)$ were prepared and used for magnetic measurements, namely $\mathrm{M}_{1}$, pure M-HFn nanoparticles, dry weight $3.1 \mathrm{mg} ; \mathrm{M}_{2}$, a mixture of M-HFn nanoparticles (39.4 wt\%) and MSR-1 whole cells (60.6 wt\%), dry weight $15.5 \mathrm{mg} ; \mathrm{M}_{3}$, a mixture of M-HFn (14.0 wt\%) and MSR-1 whole cells (86.0 wt\%), dry weight $22.5 \mathrm{mg}$; and $\mathrm{M}_{4}$, pure MSR-1 whole cells, dry weight $12.8 \mathrm{mg}$. Note that the magnetization and remanence values of this paper were calculated using the sample's dry weight. Samples were transferred into nonmagnetic capsules and stored in anoxic chamber before magnetic measurements.

\section{Transmission electronic microscopy analysis}

Magnetite cores within M-HFn nanoparticles and magnetosome magnetite in MSR-1 whole cells were examined by transmission electronic microscopy (TEM, JEOL JEM2100) operating at $200 \mathrm{kV}$. The sizes of magnetoferritin and magnetosome were analyzed using standard analytical software. The major and minor axes of magnetite were used as the length $(L)$ and width $(W)$ of the crystal, respectively. The grain size was defined as $(L+W) / 2$.

\section{Room-temperature hysteresis, first-order reversal curve (FORC) and saturation isothermal remanent magnetization (SIRM) measurements}

Room-temperature hysteresis loops, FORCs and SIRMs were measured using a VSM3900 magnetometer (Princeton Measurements Corporation, USA, sensitivity $5.0 \times 10^{-10} \mathrm{Am}^{2}$ ). A total 120 curves were measured in FORCs using an increasing field step of $0.721 \mathrm{mT}$ with an averaging time of $500 \mathrm{~ms}$. The FORC diagrams were processed using FORCinel version 1.18 software (Harrison and Feinberg 2008) with a smooth factor of 3.

\section{Low-temperature magnetic measurements}

Low-temperature magnetic measurements were taken with a Quantum Design MPMS XP-5 SQUID magnetometer (sensitivity $5.0 \times 10^{-10} \mathrm{Am}^{2}$ ). Hysteresis loops were measured at temperatures $5 \mathrm{~K}, 10 \mathrm{~K}$ and $20 \mathrm{~K}$. Lowfield magnetization curves were measured between 5 and $300 \mathrm{~K}$ in a field of $1 \mathrm{mT}$ field after the sample was cooled from 300 to $5 \mathrm{~K}$ in zero-field (zero-field cooling, $\mathrm{ZFC}$ ) and $1 \mathrm{mT}$ field (field cooling, FC), respectively. The thermal decay of saturation isothermal remanence (acquired in $2.5 \mathrm{~T}$ at $5 \mathrm{~K}$ ) was measured between 5 and $300 \mathrm{~K}$ after the sample was cooled in ZFC and FC (in a 2.5 - $\mathrm{T}$ field) from 300 to $5 \mathrm{~K}$, respectively. The AC susceptibility measurements were taken between 5 and $300 \mathrm{~K}$ at frequencies of $1,5,10,50,100,200,500$ and $1000 \mathrm{~Hz}$ in a peak AC field of $0.4 \mathrm{mT}$.

\section{Results}

\section{Grain size and mass of magnetites in samples}

Figure $1 \mathrm{a}-\mathrm{c}$ shows that the magnetite cores of the synthesized M-HFn nanoparticles were mono-dispersed, well crystalline and with a mean size of $5.3 \pm 1.2 \mathrm{~nm}(N=509)$. Each MSR-1 cell contains a single chain that consists of 10-15 octahedral magnetite magnetosomes, which have a mean size of $29.6 \pm 7.6 \mathrm{~nm}(N=311)$ (Fig. 1d-g).

Figure $1 \mathrm{~h}-\mathrm{i}$ shows the M-HFn nanoparticles adhered to MSR-1 cell surface in the mixed sample $\mathrm{M}_{2}$. Magnetite nanoparticles are separated by cell membrane and protein shell. Figure $1 \mathrm{j}$ shows the X-ray diffraction of the magnetite of M-HFn nanoparticles of Fig. 1i, confirming the crystalline ultrafine-grained magnetite in the M-HFn nanoparticles.

The proportion of magnetite in magnetoferritin and magnetosome in MSR-1 cells is $32.4 \%$ (Table 1 ) and $4 \%$ (Faivre et al. 2007), respectively. The mass of magnetite in each sample $\mathrm{M}_{1}-\mathrm{M}_{4}$ was calculated.

\section{FORCs diagram and magnetic interaction analysis}

FORCs diagrams are presented in Fig. 2. Of note, magnetostatic interactions between magnetite particles in measured samples are very weak $\left(H_{\mathrm{b}, 1 / 2}=2.1 \mathrm{mT}\right)$, due to protein and cell separations. Samples $M_{2}, M_{3}$ and $M_{4}$, containing different portions of SD magnetosome magnetite of MSR-1 whole cells, have nearly the same feature with a coercive value of $13.8 \mathrm{mT}$, and a negative region at the lower left region, a indicative of SD magnetite. No signal of sample $M_{1}$ was detectable under the used measurement condition.

\section{Hysteresis}

Room-temperature hysteresis loops of four samples are shown in Fig. 3. Hysteresis parameters are summarized in Table 1 . It is noted that the sample $M_{1}$ containing ultrafine-grained magnetite of M-HFn is a typical superparamagnetic, which has high saturation magnetization $\left(M_{\mathrm{s}}\right)$ but no detectable coercivity $\left(H_{\mathrm{c}}\right)$, consistent with previous studies (Cao et al. 2010; Tauxe et al. 1996). Sample $\mathrm{M}_{4}$ containing chain-arranged SD magnetite magnetosomes of MSR-1 cells has a potbelly shape loop, a uniaxial single-domain behavior. Samples $M_{2}$ and $M_{3}$ containing both M-HFn and MSR-1 have $H_{\mathrm{c}}$ values of $1.8 \mathrm{mT}$ and $4.5 \mathrm{mT}$ and $M_{\mathrm{s}}$ values of $4.1 \mathrm{Am}^{2} \mathrm{~kg}^{-1}$ and $1.6 \mathrm{Am}^{2} \mathrm{~kg}^{-1}$, respectively, varying with the portions of $\mathrm{SP}$ and SD components.

The hysteresis loops measured at low temperature (Fig. 4 and Table 2) showed that all samples have the capacity to carry remanence at $T \leq 20 \mathrm{~K}$. Their $M_{\mathrm{s}}$ and saturation remanence $\left(M_{\mathrm{rs}}\right)$ are $23.7,10.9,3.8$ and $0.4 \mathrm{Am}^{2} \mathrm{~kg}^{-1}$ and $7.4,3.4,1.2$ and $0.2 \mathrm{Am}^{2} \mathrm{~kg}^{-1}$ at $5 \mathrm{~K}$, respectively, for 

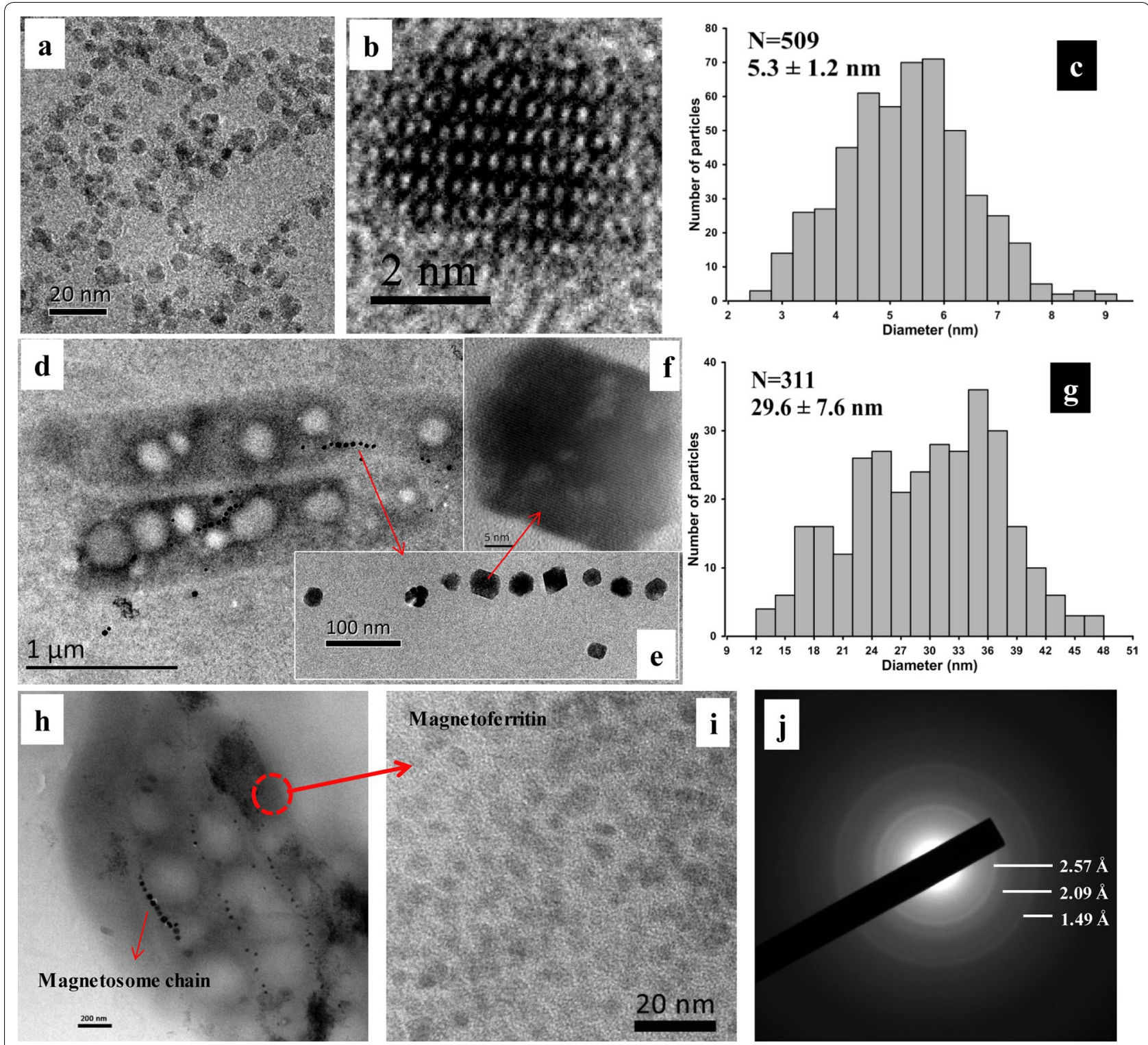

Fig. 1 TEM micrographs of M-HFn nanoparticles and MSR-1 cells. a M-HFn nanoparticles; $\mathbf{b}$ an enlarged M-HFn core; c size distribution histogram of magnetite cores in M-HFn nanoparticles. $\mathbf{d}$ MSR-1 whole cells; e magnetosomes chain; $\mathbf{f}$ a magnetite magnetosome; $\mathbf{g}$ size distribution histogram of magnetosomes in MSR-1 cells. $\mathbf{h}-\mathbf{j}$ Mixed M-HFn nanoparticles and MSR-1 cell of sample $\mathrm{M}_{2}$. $\mathbf{j}$ An electron diffraction pattern of the M-HFn nanoparticles of (i)

$\mathrm{M}_{1}, \mathrm{M}_{2}, \mathrm{M}_{3}$ and $\mathrm{M}_{4}$. From 5 to $20 \mathrm{~K}, M_{\mathrm{s}}$ of sample $\mathrm{M}_{1}, \mathrm{M}_{2}$ and $\mathrm{M}_{3}$ decreases slightly but the $M_{\mathrm{rs}}$ drops significantly due to thermal unblocking of contained ultrafine-grained magnetite; for sample $\mathrm{M}_{4}$, the $M_{\mathrm{s}}$ and $M_{\mathrm{rs}}$ remain nearly constant, while the $H_{\mathrm{c}}$ drops from 70 to $50 \mathrm{mT}$. Interestingly, although the $H_{\mathrm{c}}$ values of each sample dramatically decrease with temperature increment, it is noted that the samples $M_{1}, M_{2}$ and $M_{3}$, in spite of difference concentration of M-HFn, have very similar coercivity values at $5 \mathrm{~K}$,
$10 \mathrm{~K}$ and $20 \mathrm{~K}$. This can be explained by the dominance of the ultrafine-grained magnetite in M-HFn.

\section{Low-temperature magnetic variation, blocking temperature and Verwey transition}

Figure 5 shows the temperature dependence of lowfield $(1.0 \mathrm{mT})$ magnetization from 5 to $300 \mathrm{~K}$ after the ZFC and FC treatments. The samples $M_{1}, M_{2}$ and $M_{3}$ display similar behaviors but different blocking temperatures $\left(T_{\mathrm{b}}\right): 35 \mathrm{~K}, 34.1 \mathrm{~K}$ and $27.1 \mathrm{~K}$, respectively. 
Table 1 Hysteresis parameters obtained from room-temperature measurements

\begin{tabular}{llllllll}
\hline Samples & Weight $\mathbf{( m g )}$ & $\begin{array}{l}\text { Magnetite } \\
\text { in M-HFn }(\mathbf{m g})\end{array}$ & $\begin{array}{l}\text { Magnetite } \\
\text { in MSR-1 }(\mathbf{m g})\end{array}$ & $\boldsymbol{M}_{\mathbf{s}}\left(\mathbf{A m}^{\mathbf{2}} \mathbf{k g}^{-\mathbf{1}}\right)$ & $\boldsymbol{M}_{\mathbf{r s}}\left(\mathbf{A m}^{\mathbf{2}} \mathbf{k g}^{-\mathbf{1}}\right)$ & $\boldsymbol{H}_{\mathbf{c}}(\mathbf{m T})$ & $\boldsymbol{H}_{\mathbf{c r}}(\mathbf{m T})$ \\
\hline$M_{1}$ & 3.1 & 1.00 & 0 & 9.6 & 0 & 0 & 0 \\
$M_{2}$ & 15.5 & 1.98 & 0.38 & 4.1 & 0.07 & 1.8 & 15.7 \\
$M_{3}$ & 22.5 & 1.02 & 0.77 & 1.6 & 0.09 & 4.5 & 15.2 \\
$M_{4}$ & 12.8 & 0 & 0.51 & 0.3 & 0.11 & 9.6 \\
\hline
\end{tabular}

$M_{\mathrm{s}^{\prime}}$ saturation magnetization; $M_{\mathrm{r}{ }^{\prime}}$ saturation remanence; $H_{\mathrm{c}^{\prime}}$ coercivity force; $H_{\mathrm{cr}}$ remanence coercivity

Calculation of magnetite mass in magnetoferritin (M-HFn)

$W_{\text {magnetite }}=C_{\text {magnetite }} \times\left(4 / 3 \times \pi \times(d / 2)^{3}\right)$

$W_{\text {ferritin }}=M_{\text {ferritin }} / \mathrm{NA}$

where density of magnetite, $C_{\text {magnetite }}=5.18 \mathrm{~g} / \mathrm{cm}^{3}$; diameter of the magnetite core in magnetoferritin, $d=5.31 \mathrm{~nm}$; molecular weight of ferritin, $M_{\text {ferritin }}=509 \mathrm{kDa}$; Avogadro's constant, NA $=6.02 \times 10^{23}$
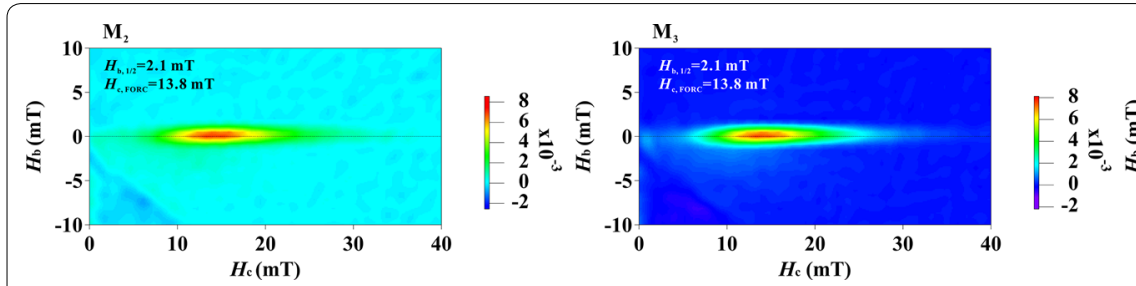

Fig. 2 FORCs diagrams of samples $M_{2}, M_{3}$ and $M_{4}$ measured at room temperature

Of note, the ZFC and FC curves of $\mathrm{M}_{1}$ sample merges at about $60 \mathrm{~K}$, while the ZFC and FC curves of $\mathrm{M}_{2}$ and $\mathrm{M}_{3}$ are diverged and join at much high temperatures, indicating the presence of magnetosome magnetite. On the contrary, sample $\mathrm{M}_{4}$ containing pure MTB displays totally different trend in the ZFC and FC curves. On the warming curve, the magnetization of $\mathrm{M}_{4}$ after either ZFC or FC treatment increases rapidly at temperature between 90 and $130 \mathrm{~K}$, indicative of the Verwey transition temperature $\left(T_{\mathrm{V}}\right)$ of magnetite around $100 \mathrm{~K}$.

Thermal demagnetization curves of SIRMs acquired in a $2.5 \mathrm{~T}$ field at $5 \mathrm{~K}$ for samples $\mathrm{M}_{1}, \mathrm{M}_{2}$ and $\mathrm{M}_{3}$ showed a rapid drop from 5 to $20 \mathrm{~K}$ (Fig. 6). The $2.5 \mathrm{~T}$ ZFC and FC curves of $M_{1}$ are nearly superimposed. The rapid drop of SIRM is due to unblocking (Brown 1963). The median unblocking temperature in the FC curve is $T_{\mathrm{bm}}=10.5 \mathrm{~K}$. The remanence of ZFC and FC decreased to zero near at $25 \mathrm{~K}$, which indicate all the particles are unblocked. As expected, the decay curve of the sample $\mathrm{M}_{4}$ containing pure MTB sample shows a Verwey transition behavior around $100 \mathrm{~K}$; the calculated $\delta$-ratio is 1.37. The Verwey transition in samples $M_{2}$ and $M_{3}$ is nearly completely suppressed, although these two samples contain significant amount of magnetosome magnetite.

\section{Frequency dependence of AC susceptibility}

AC magnetic susceptibility measurements yield both a real component $\left(X^{\prime}\right)$ and an imaginary component $\left(\chi^{\prime \prime}\right)$ (Fig. 7). It is clear that $M_{1}, M_{2}$ and $M_{3}$ containing the ultrafine-grained M-HFn magnetite display generally similar variation with temperature and frequency: on warming, $X^{\prime}$ increased rapidly up to $34-46 \mathrm{~K}$ and decreased up to $300 \mathrm{~K}$, while $\chi^{\prime \prime}$ increased rapidly up to $25-34 \mathrm{~K}$ and decreasing again up to $80 \mathrm{~K}$. Above this temperature, $X^{\prime \prime}$ approaches zero. The peak values of $\chi^{\prime}$ decrease with increasing frequency, and blocking/ unblocking temperature identified by peak values of $X^{\prime}$ increases with increasing frequency (see inset in Fig. 7). The peak values of $\chi^{\prime}$ and $\chi^{\prime \prime}$ decreased with decreasing proportions of M-HFn magnetite in the samples. A slight concave appears in the $X^{\prime \prime}-T$ curve around $80-100 \mathrm{~K}$ in $\mathrm{M}_{3}$ sample probably due to the effect of SD magnetosome magnetite.

Sample $\mathrm{M}_{4}$ containing only MTB cells has a totally different behavior in the $\chi^{\prime}-T$ and $\chi^{\prime \prime}-T$ curves. Both $\chi^{\prime}$ and $\chi^{\prime \prime}$ increased slightly up to $85 \mathrm{~K}$ and then increased much more rapidly between 85 and $135 \mathrm{~K}$, corresponding to the Verwey transition of magnetite. Above $130 \mathrm{~K}, \chi^{\prime}$ continuously increased up to $300 \mathrm{~K}$, while $\chi^{\prime \prime}$ decreased slightly. $\mathrm{M}_{4}$ 's $\chi^{\prime}$ shows frequency dependence, and the values of $\chi^{\prime}$ decrease with increasing frequencies. 


\section{M1}

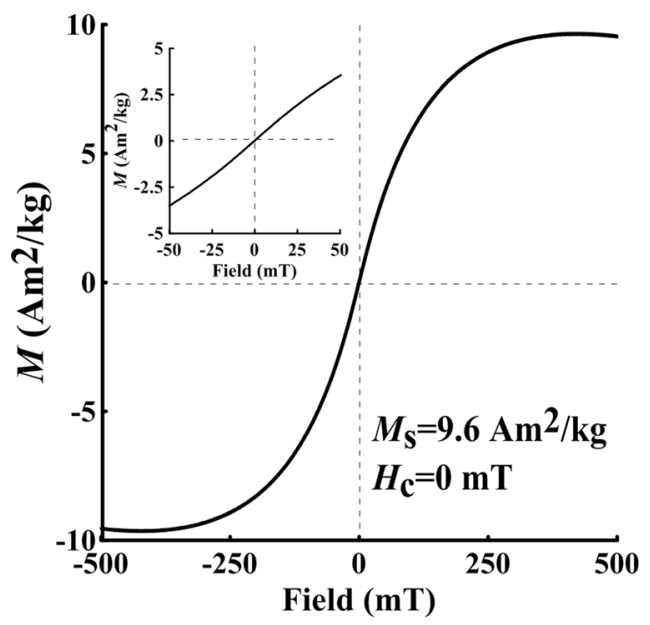

M3

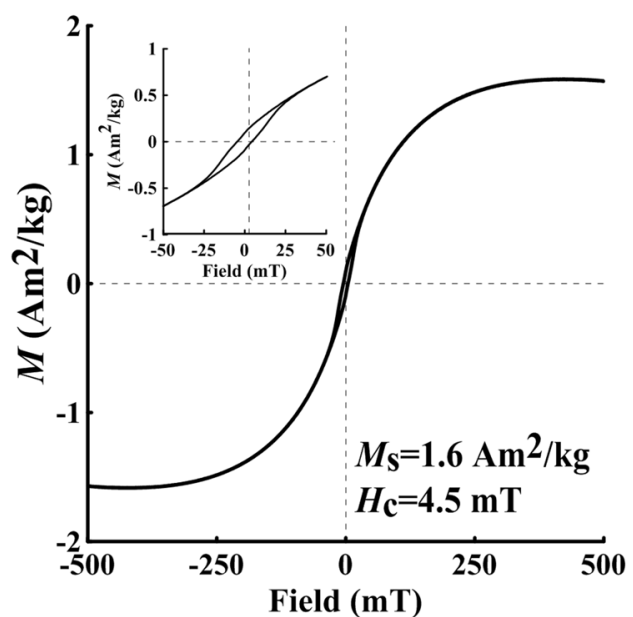

M2

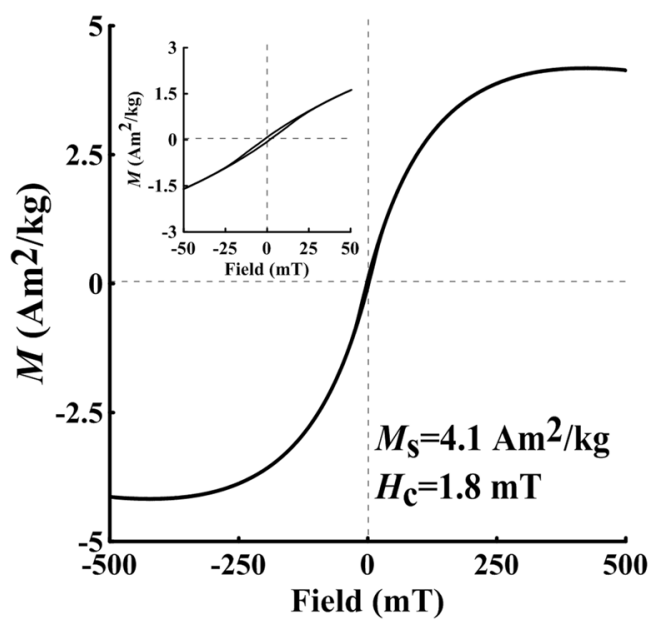

M4

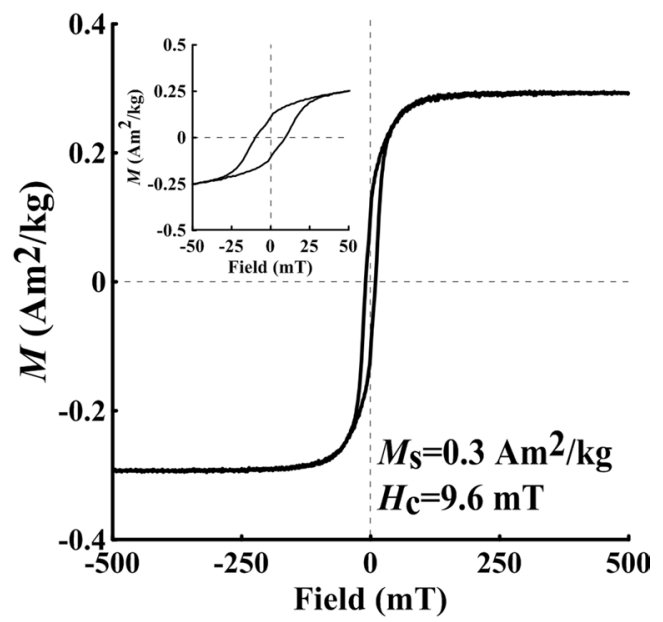

Fig. 3 Hysteresis loops of four samples measured at room temperature

\section{Discussion and conclusions}

\section{Magnetic signature of SP magnetite}

Ferritin-based ultrafine-grained magnetites can be taken as ideal sample for superparamagnetism study, because of (1) controllable and uniform grain size, (2) mono-dispersed, (3) lack of magnetic interaction, (4) good availability and (5) "ideal" SP behaviors at room temperature. Hysteresis loop confirmed that the ultrafine-grained magnetites in sample $M_{1}$ with a mean size of $5.3 \pm 1.2 \mathrm{~nm}$ are superparamagnetic at room temperature (Fig. 3), which corresponds to a $T_{\mathrm{b}}$ of $35 \mathrm{~K}$ (Fig. 5); at $T<T_{\mathrm{b}}$, they can carry remanence (Fig. 6). Their frequency dependences of AC magnetic susceptibility are significant, e.g., peak temperature and value of $\mathrm{AC}$ susceptibilities decrease with frequency from $1 \mathrm{~Hz}$ to $1 \mathrm{kHz}$ (Fig. 7). Cao et al. (2010) previously determined the value of pre-exponential factor $f_{0}$ in the Néel-Arrhenius equation from AC susceptibility data of M-HFn nanoparticles with a mean grain size of $3.9 \pm 1.2 \mathrm{~nm}:(9.2 \pm 7.9) \times 10^{10} \mathrm{~Hz}$ and the extrapolated value of $M_{\mathrm{rs}} / M_{\mathrm{s}}=0.5$ and $B_{\mathrm{cr}} / B_{\mathrm{c}}=1.12$ at $0 \mathrm{~K}$, which suggests the ferrimagnetic M-HFn is dominated by uniaxial anisotropy.

Grain size effect of SP magnetite is an interesting subject to probe. In the combination of data of this study and available magnetic results of magnetoferritins (Cai et al. 2015; Yang et al. 2017; Zhang et al. 2017), it is noted that $M_{\mathrm{s}}, T_{\mathrm{b}}, H_{\mathrm{c}}$ and peroxidase-like 


\section{M1}

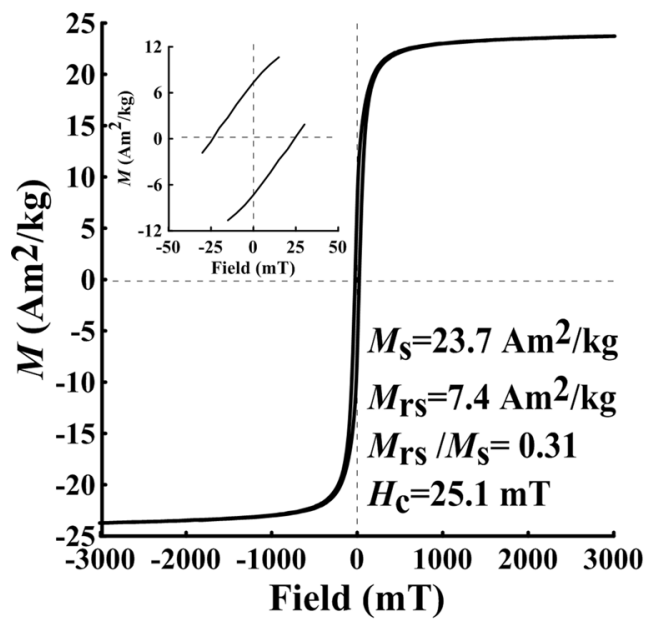

M3

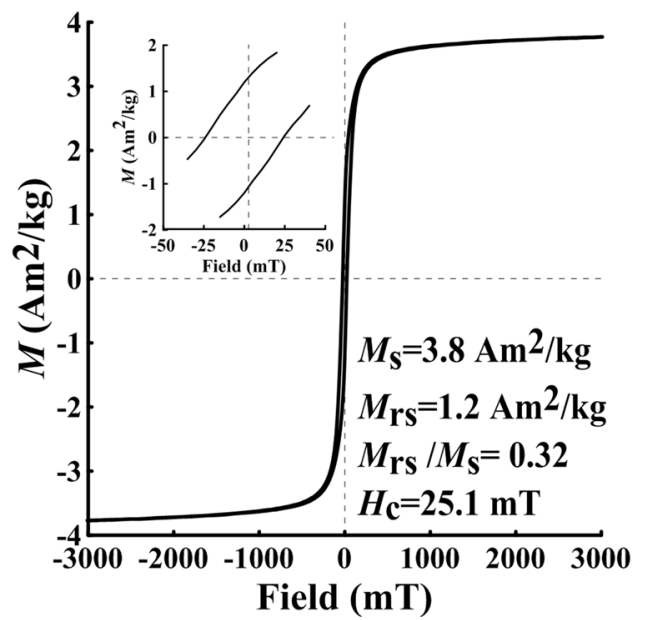

$\mathbf{M}_{2}$

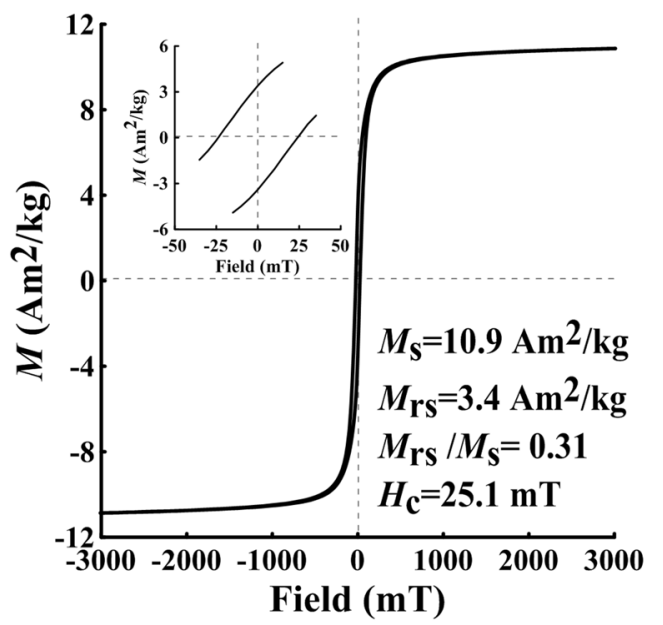

M4

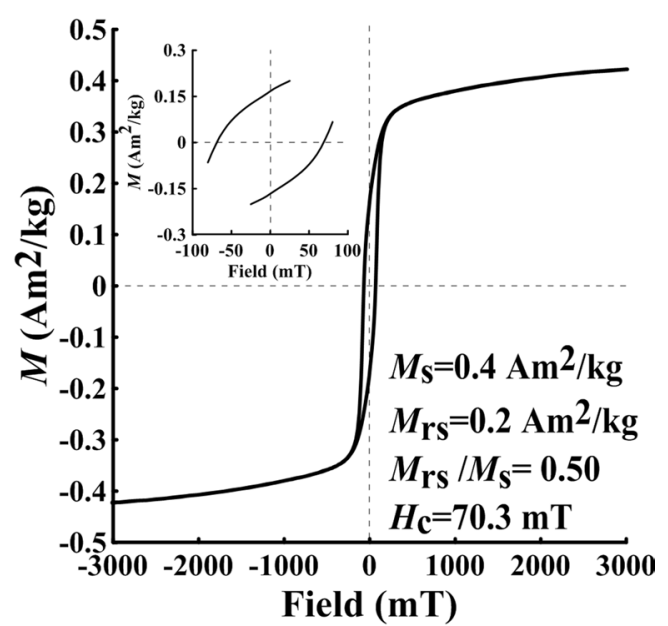

Fig. 4 Hysteresis loops of four samples measured at $5 \mathrm{k}$

Table 2 Hysteresis parameters obtained from low-temperature measurements

\begin{tabular}{|c|c|c|c|c|c|c|c|c|c|}
\hline \multirow[t]{2}{*}{ Samples } & \multicolumn{3}{|c|}{$H_{\mathrm{c}}(\mathrm{mT})$} & \multicolumn{3}{|c|}{$M_{\mathrm{s}}\left(\mathrm{Am}^{2} \mathrm{~kg}^{-1}\right)$} & \multicolumn{3}{|c|}{$M_{\mathrm{rs}}\left(\mathrm{Am}^{2} \mathrm{~kg}^{-1}\right)$} \\
\hline & $5 \mathrm{~K}$ & $10 \mathrm{~K}$ & $20 \mathrm{~K}$ & $5 \mathrm{~K}$ & $10 \mathrm{~K}$ & $20 \mathrm{~K}$ & $5 \mathrm{~K}$ & $10 \mathrm{~K}$ & $20 \mathrm{~K}$ \\
\hline$M_{1}$ & 25.1 & 10.0 & 0 & 23.7 & 23.7 & 22.6 & 7.4 & 4.1 & 0.4 \\
\hline$M_{2}$ & 25.1 & 10.0 & 0 & 10.9 & 10.8 & 10.8 & 3.4 & 1.9 & 0.3 \\
\hline$M_{3}$ & 25.1 & 10.0 & 0 & 3.8 & 3.7 & 3.7 & 1.2 & 0.7 & 0.2 \\
\hline$M_{4}$ & 70.3 & 65.3 & 50.2 & 0.4 & 0.4 & 0.4 & 0.2 & 0.2 & 0.2 \\
\hline
\end{tabular}

activity enhance with grain sizes. Recently, Cai et al. found that the synthesized M-HFn containing $\mathrm{Fe}_{2} \mathrm{O}_{3}$ cores with a mean grain size of $2.2 \mathrm{~nm}$ has a high longitudinal relaxivity value of $0.94 \mathrm{mM}^{-1} \mathrm{~s}^{-1}$ and they proposed it as a potential positive contrast agent for magnetic resonance angiography (Cai et al. 2018). Efficiency of hyperthermia using ultrafine-grained iron oxides is also related to grain size of magnetic minerals 

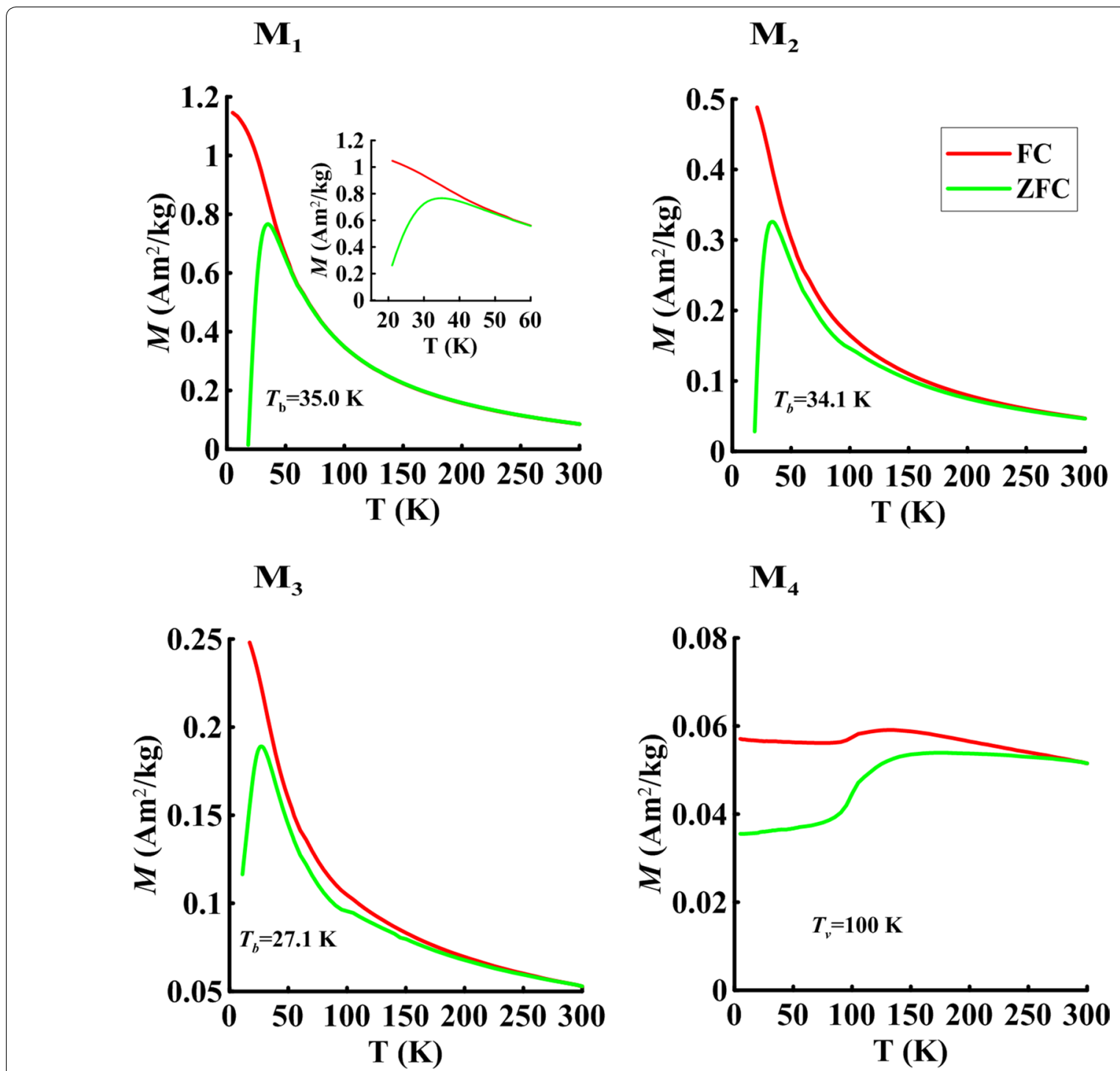

Fig. 5 Low-field (1.0 mT) magnetization as a function of temperature (5-300 K) measured after zero-field-cooling (ZFC) and field-cooling (FC) treatments

(Banobre-Lopez et al. 2013; Deatsch and Evans 2014). Therefore, grain size effects of SP magnetites on mineral magnetism and related applications for biomedical detection and therapy need investigations.

\section{Magnetic signature of bacterial SD magnetite}

Over the past several decades, there are few studies on their magnetic properties of MTB samples (Ding et al. 2010; Li et al. 2009, 2010; Moskowitz et al. 1993; Prozorov et al. 2007; Weiss et al. 2004; Wang et al. 2015). The cultivated MSR-1 cells used in current study $\left(\mathrm{M}_{4}\right.$ sample) contain in average 10-15 magnetite magnetosomes with a mean size of $29.6 \pm 7.6 \mathrm{~nm}$, arranged in single chains (Fig. 1d-g); the size of magnetosome magnetite in MSR-1 is slightly smaller than $38 \mathrm{~nm}$ of the wild-type MSR-1 (Ding et al. 2010), $44 \mathrm{~nm}$ of Magnetospirillum strain XM-1 (Wang et al. 2015) and $42 \mathrm{~nm}$ of Magnetospirillum magneticum AMB-1 (Li et al. 2009), probably, due to the strain degradation in cultivation. Strain degradation of MSR-1 may be caused by genetic instability (Ullrich et al. 2005), which is a common cause of strain degradation in industrial production (Gravius et al. 1993). The FORC diagram is nicely characterized by a rather narrow distribution around $H_{\mathrm{C}, \mathrm{FORC}} \sim 13.8 \mathrm{mT}$ along the horizontal axis, the so-called central ridge distribution (Egli et al. 2010) and a negative area in lower left region (Fig. 3). The $T_{\mathrm{v}}$ of $100 \mathrm{~K}$ is comparable to other cultivated MTB and uncultivated MTB (Li et al. 2010; Ding et al. 2010; Pan 

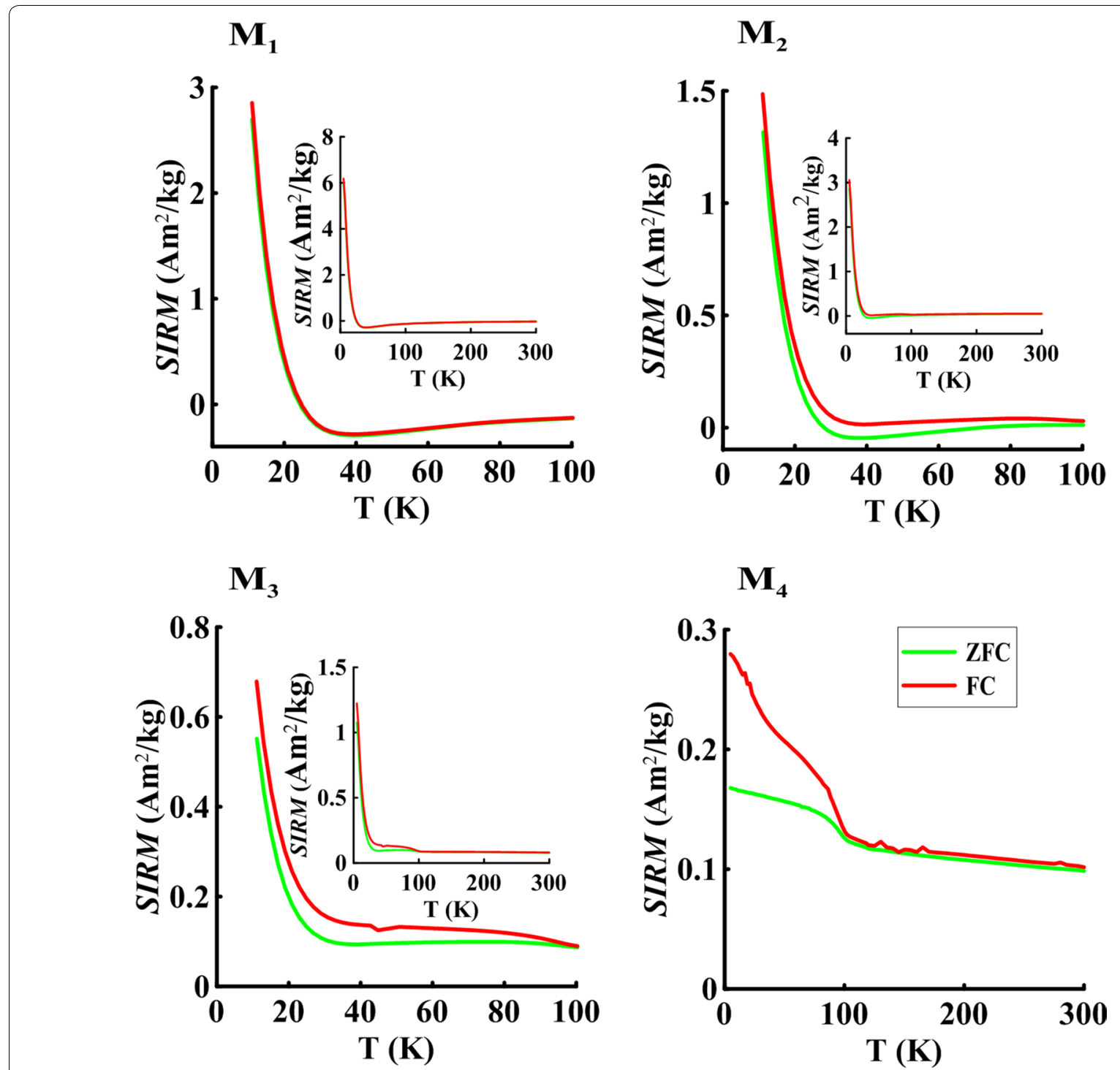

Fig. 6 Decay curves of saturation isothermal remanent magnetization acquired in a 2.5 T field after zero-field-cooling (ZFC) and field-cooling (FC) treatments

et al. 2005b; Moskowitz et al. 1993; Wang et al. 2015), confirming the lower $T_{\mathrm{v}}$ as a good indicative of MTBproduced magnetites.

\section{Analysis of SP contribution in mixed samples}

In this study two mixed samples with different portions of SP and SD magnetite were magnetically characterized. As mentioned previously, SP magnetite and SD magnetite in measured samples are well separated by protein and membranes; it led to magnetic interaction ignorable. With the known composition and grain size distribution, results of samples $\mathrm{M}_{2}$ (containing $84 \mathrm{wt} \%$ SP magnetite and $16 \mathrm{wt} \%$ SD magnetite) and $\mathrm{M}_{3}$ (containing $57 \mathrm{wt} \%$ SP magnetite and $43 \mathrm{wt} \%$ SD magnetite) provide us unambiguous constraints on contributions of either SP or SD component.

The room-temperature FORC diagrams for $\mathrm{M}_{2}$ and $\mathrm{M}_{3}$ are similar to that of $\mathrm{M}_{4}$ (Fig. 3), which is clearly signal of chain-arranged SD magnetosome magnetites. In contrast, the bulk magnetic properties, e.g., $H_{\mathrm{c}}, M_{\mathrm{s}}$ and $M_{\mathrm{rs}}, \chi^{\prime}$ and $\chi^{\prime \prime}$, measured at low temperatures of sample $\mathrm{M}_{2}$ and $\mathrm{M}_{3}$ (Table 2; Figs. 4, 5, 6, 7) are controlled by the SP magnetite. Comparing samples $\mathrm{M}_{1}$ to $\mathrm{M}_{3}$, at $T \leq 20 \mathrm{~K}, M_{\mathrm{rs}}$ values decay rapidly with both temperature and SP concentrations; the $M_{\mathrm{s}}$ decay with SP concentrations but not with temperatures (Table 2); it suggests that the decay rates of $M_{\mathrm{rs}}$ and $M_{\mathrm{s}}$ 


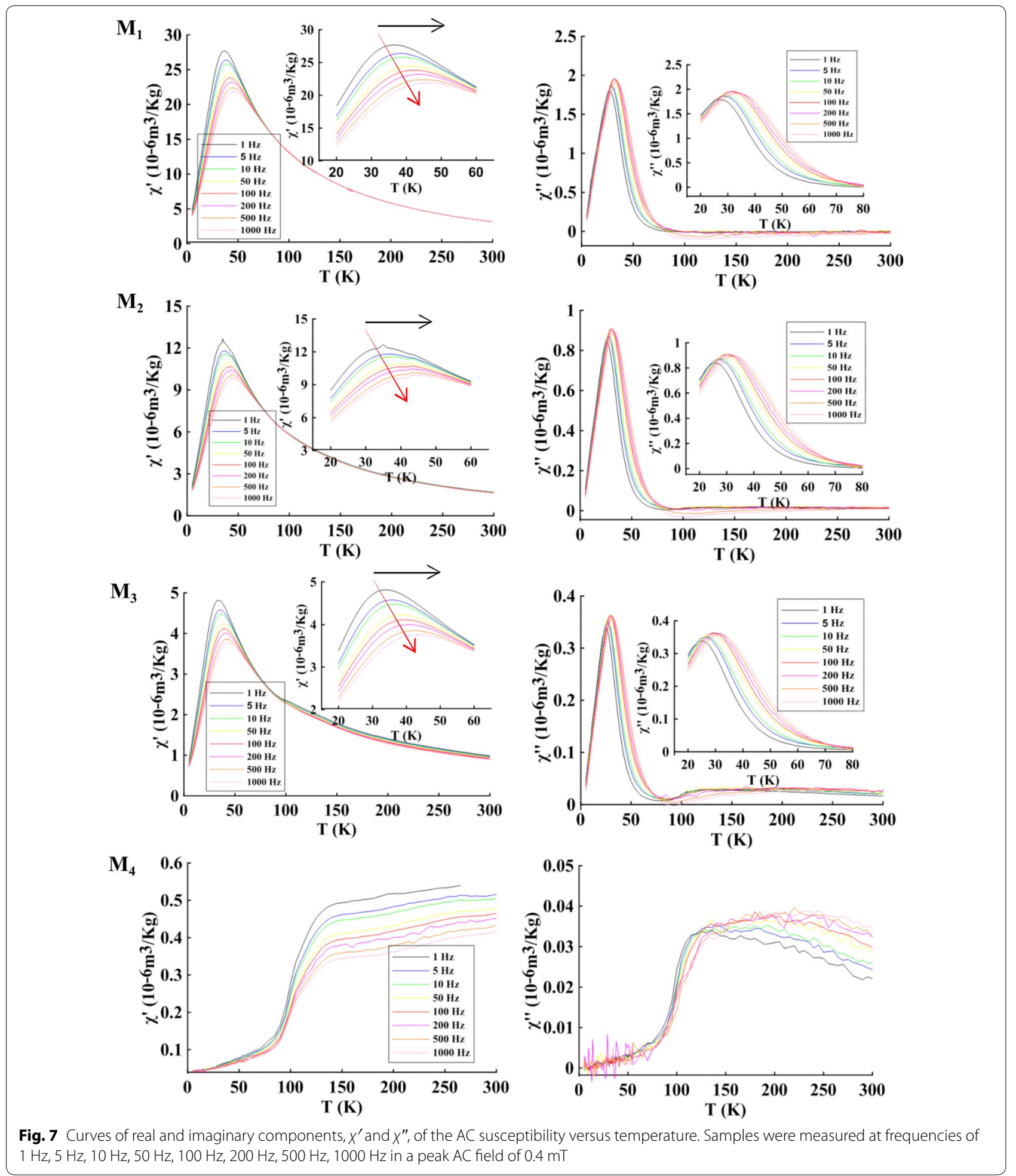

at $T<20 \mathrm{~K}$ may be useful in estimating SP component in samples.

At room temperature, as expected, $M_{\mathrm{rs}} / M_{\mathrm{s}}$ of samples $\mathrm{M}_{4}$ and $\mathrm{M}_{2}$ decrease from 0.37 to 0.02 while their
$H_{\mathrm{rs}} / H_{\mathrm{c}}$ increase from 1.58 to 8.72 , respectively, reflecting significant influence of SP component to the hysteresis (Tauxe et al. 1996; Dunlop 2002). However, it should be aware that the measured mixed samples 
contained only non-interacting SP and SD magnetite. More measurements on samples with different concentrations and compositions are needed.

\section{Identification of fossil magnetite in sediments}

Although it has been found that present-day magnetotactic bacteria are ubiquitous in a diverse range of aquatic environments, identification of fossil magnetite from sediments as well as deciphering their paleoenvironmental and paleomagnetic records is somehow not straightway, because of relatively low concentrations of magnetofossils in sediments and mixtures with abundant detrital origin single- and multi-domain magnetites. This study confirms the magnetosome magnetite in MSR-1 does have a $T_{\mathrm{v}}$ around $100 \mathrm{~K}$ and central ridge behavior in FORCs. Through extensive investigation on both uncultivated and cultivated MTBs over past decades, it has been well demonstrated that magnetofossils can be identified through measurement of combination of the delta ratio (Moskowitz et al. 1993), FORCs (Egli et al. 2010), identification of lower $T_{\mathrm{v}}$ temperatures (Chang et al. 2014; Pan et al. 2005b), ferromagnetic resonance (Weiss et al. 2004), unique chemical signatures (Amor et al. 2015), Fe isotope signature (Amor et al. 2016), as well as TEM examinations. Recently, Lin et al. found through genetic and genomic analyses that magnetotactic bacteria may appear in Archean time, indicative of an Archean geomagnetic field and a small amount of oxygen in oceanic habitats (Lin et al. 2017). To uncover potential paleoenvironmental and paleomagnetic records carried by magnetofossils in sediments over geological time is desired.

\section{Authors' contributions}

YXP designed this work. TWZ carried out the experiments. YXP and TWZ analyzed data and wrote the manuscript. Both authors read and approved the final manuscript.

\footnotetext{
Authors' information

TWZ is now a research associate of Biogeomagnetism Laboratory at Institute of Geology and Geophysics, Chinese Academy of Sciences. He obtained bachelor degree of biotechnology at Anhui University and master degree of microbiology at China Agriculture University under the supervision of Prof. Ying Li. He joined the Biogeomagnetism Laboratory at Institute of Geology and Geophysics in 2012. His current main research interests include biomineralization of iron oxides and medical magnetic nanomaterials. YXP is now a research professor at Institute of Geology and Geophysics, Chinese Academy of Sciences (IGGCAS). He obtained bachelor and master degrees of geology at the China University of Geosciences under the supervision of Prof. Naihe Huang, a Ph.D. degree of geophysics under the supervision of Prof. Rixang Zhu. He joined the Paleomagnetism and Geochronology Laboratory at Institute of Geology and Geophysics in 1998. He visited the University of Liverpool in 2000 as a RS Royal Fellowship where he worked with Prof. John Shaw on paleointensity study and Munich University in 2003-2004 as an AvH Fellowship where he worked with Prof. Nikolai Petersen on biogeomagnetism. $\mathrm{He}$ is the founder director of the Biogeomagnetism Laboratory at IGGCAS. His current main research interests include rock magnetism, paleointensity, biogeomagnetism, biomineralization and planetary magnetism.
}

\section{Author details}

${ }^{1}$ Biogeomagnetism Group, Key Laboratory of Earth and Planetary Physics, Institute of Geology and Geophysics, Institutions of Earth Science, Chinese Academy of Sciences, Beijing, China. ${ }^{2}$ Evolution and Development of Magnetotactic Multicellular Organisms, Chinese Academy of Sciences, Beijing, China. ${ }^{3}$ College of Earth and Planetary Sciences, University of Chinese Academy of Sciences, Beijing, China.

\section{Acknowledgements}

We thank Tang Xu and Gu Lixin at IGGCAS for TEM analysis. We appreciate John Tarduno, Adrian Muxworthy and two anonymous reviews for their very constructive comments that significantly improve this manuscript.

\section{Competing interests}

The authors declare that they have no competing interests.

\section{Availability of data and materials}

Data are present in supporting files. Other data are also available by requesting to YXP and TWZ.

\section{Funding}

This work was supported by the Frontier Science Key Project of CAS and NSFC grants (41621004).

\section{Publisher's Note}

Springer Nature remains neutral with regard to jurisdictional claims in published maps and institutional affiliations.

Received: 2 September 2018 Accepted: 14 December 2018 Published online: 24 December 2018

\section{References}

Amor M, Busigny V, Durand-Dubief M, Tharaud M, Ona-Nguema G, Gélabert A, Alphandéry E, Menguy N, Benedetti MF, Chebbi I, Guyot F (2015) Chemical signature of magnetotactic bacteria. Proc Natl Acad Sci USA 112(6):1699-1703. https://doi.org/10.1073/pnas.1414112112

Amor M, Busigny V, Louvat P, Gélabert A, Cartigny P, Durand-Dubief M, OnaNguema G, Alphandéry E, Chebbi I, Guyot F (2016) Mass-dependent and -independent signature of Fe isotopes in magnetotactic bacteria. Science 352(6286):705-708

Amstad E, Textor M, Reimhult E (2011) Stabilization and functionalization of iron oxide nanoparticles for biomedical applications. Nanoscale 3(7):2819-2843. https://doi.org/10.1039/c1 nr10173k

Banobre-Lopez M, Teijeiro A, Rivas J (2013) Magnetic nanoparticle-based hyperthermia for cancer treatment. Rep Pract Oncol Radiother 18:397-400

Bazylinski DA, Frankel RB (2004) Magnetosome formation in prokaryotes. Nat Rev Microbiol 2(3):217-230. https://doi.org/10.1038/nrmicro842

Bedanta S, Kleemann W (2009) Supermagnetism. J Phys D-Appl Phys. https:// doi.org/10.1088/0022-3727/42/1/013001

Blakemore R (1975) Magnetotactic bacteria. Science 190(4212):377-379. https ://doi.org/10.1126/science.170679

Bonnemain B (1998) Superparamagnetic agents in magnetic resonance imaging: physicochemical characteristics and clinical applications-a review. J Drug Target 6(3):167-174

Brown WF (1963) Thermal fluctuations of a single-domain particle. Phys Rev 130(5):1677. https://doi.org/10.1103/physrev.130.1677

Cai Y, Cao C, He X, Yang C, Tian L, Zhu R, Pan Y (2015) Enhanced magnetic resonance imaging and staining of cancer cells using ferrimagnetic $\mathrm{H}$-ferritin nanoparticles with increasing core size. Int J Nanomed 10:2619-2634. https://doi.org/10.2147/IJN.S80025

Cai Y, Wang Y, Xu H, Cao C, Zhu R, Tang X, Zhang T, Pan Y (2018) Positive magnetic resonance angiography by ultrafine ferritin-based iron oxide nanoparticles. Nanoscale. https://doi.org/10.1039/c8nr06812g

Cao C, Tian L, Liu Q, Liu W, Chen G, Pan Y (2010) Magnetic characterization of noninteracting, randomly oriented. Nanometer-scale ferrimagnetic particles. J Geophys Res 115:B07103. https://doi.org/10.1029/2009JB006855 
Cao C, Wang X, Cai Y, Sun L, Tian L, Wu H, He X, Lei H, Liu W, Chen G, Zhu R, Pan $Y$ (2014) Targeted in vivo imaging of microscopic tumors with ferritinbased nanoprobes across biological barriers. Adv Mater 26(16):25662571. https://doi.org/10.1002/adma.201304544

Chang L, Roberts AP, Winklhofer M, Heslop D, Dekkers MJ, Krijgsman W, Gerald JDF, Smith P (2014) Magnetic detection and characterization of biogenic magnetic minerals: a comparison of ferromagnetic resonance and firstorder reversal curve diagrams. J Geophys Res-Solid Earth 119(8):61366158. https://doi.org/10.1002/2014jb011213

Channell JET, Hodell DA, Margari V, Skinner LC, Tzedakis PC, Kesler MS (2013a) Biogenic magnetite, detrital hematite, and relative paleointensity in Quaternary sediments from the Southwest Iberian Margin. Earth Planet Sci Lett 376:99-109. https://doi.org/10.1016/j.epsl.2013.06.026

Channell JET, Ohneiser C, Yamamoto Y, Kesler MS (2013b) Oligocene-Miocene magnetic stratigraphy carried by biogenic magnetite at sites U1334 and U1335 (equatorial Pacific Ocean). Geochem Geophys Geosyst 14(2):265282. https://doi.org/10.1029/2012gc004429

Creer KM (1961) Superparamagnetism in red sandstones. Geophys J R Astron Soc 5(1):16-28

Deatsch QE, Evans BA (2014) Heating efficiency in magnetic nanoparticle hyperthermia. J Magn Magn Mater 354:163-172

Ding Y, Li J, Liu J, Yang J, Jiang W, Tian J, Li Y, Pan Y, Li J (2010) Deletion of the $\mathrm{ftsZ}$-Like gene results in the production of superparamagnetic magnetite magnetosomes in Magnetospirillum gryphiswaldense. J Bacteriol 192(4):1097-1105. https://doi.org/10.1128/jb.01292-09

Dunlop DJ (1973) Superparamagnetic and single-domain threshold sizes in magnetite. J Geophys Res 78(11):1780-1793. https://doi.org/10.1029/ JB078i011 p01780

Dunlop DJ (2002) Theory and application of the day plot $\left(M_{\mathrm{rS}} / \mathrm{M}_{\mathrm{s}}\right.$ versus $\mathrm{H}_{\mathrm{cr}} /$ $\left.H_{C}\right)$ 1. Theoretical curves and tests using titanomagnetite data. J Geophys Res. https://doi.org/10.1029/2001jb000486

Egli R, Chen AP, Winklhofer M, Kodama KP, Horng CS (2010) Detection of noninteracting single domain particles using first-order reversal curve diagrams. Geochem Geophys Geosyst. https://doi.org/10.1029/2009g c002916

Faivre D, Schuler D (2008) Magnetotactic bacteria and magnetosomes. Chem Rev 108:4875-4898

Faivre D, Bottger LH, Matzanke BF, Schuler D (2007) Intracellular magnetite biomineralization in bacteria proceeds by a distinct pathway involving membrane-bound ferritin and an iron(II) species. Angew Chem 46(44):8495-8499. https://doi.org/10.1002/anie.200700927

Fan K, Cao C, Pan Y, Lu D, Yang D, Feng J, Song L, Liang M, Yan X (2012) Magnetoferritin nanoparticles for targeting and visualizing tumour tissues. Nat Nanotechnol 7:459-464

Gao L, Fan K, Yan X (2017) Iron oxide nanozyme: a multifunctional enzyme mimetic for biomedical applications. Theranostics 7(13):3207-3227. https ://doi.org/10.7150/thno.19738

Gravius B, Bezmalinovic T, Hranueli D, Cullum J (1993) Genetic instability and strain degeneration in streptomycesrimosus. Appl Environ Microbiol 7(59):2220-2228

Harrison RJ, Feinberg JM (2008) FORCinel: an improved algorithm for calculating first-order reversal curve distributions using locally weighted regression smoothing. Geochem Geophys Geosyst. https://doi. org/10.1029/2008gc001987

Hergt R, Andra W, d'Ambly CG, Hilger I, Kaiser WA, Richter U, Schmidt HG (1998) Physical limits of hyperthermia using magnetite fine particles. IEEE Trans Magn 34(5):3745-3754. https://doi.org/10.1109/20.718537

Hergt R, Dutz S, Roeder M (2008) Effects of size distribution on hysteresis losses of magnetic nanoparticles for hyperthermia. J Phys-Condens Matter. https://doi.org/10.1088/0953-8984/20/38/385214

Jogler C, Schuler D (2009) Genomics, genetics, and cell biology of magnetosome formation. Annu Rev Microbiol 63:501-521. https://doi. org/10.1146/annurev.micro.62.081307.162908

Jordan A, Scholz R, Wust P, Fahling H, Felix R (1999) Magnetic fluid hyperthermia (MFH): cancer treatment with AC magnetic field induced excitation of biocompatible superparamagnetic nanoparticles. J Magn Magn Mater 201:413-419. https://doi.org/10.1016/s0304-8853(99)00088-8

Kirschvink JL (1980) South-seeking magnetic bacteria. J Exp Biol 86:345-347

Kopp RE, Kirschvink JL (2008) The identification and biogeochemical interpretation of fossil magnetotactic bacteria. Earth Sci Rev 86(1-4):42-61. https ://doi.org/10.1016/j.earscirev.2007.08.001
Kopp RE, Raub TD, Schumann D, Vali H, Smirnov AV, Kirschvink JL (2007) Magnetofossil spike during the Paleocene-Eocene thermal maximum: ferromagnetic resonance, rock magnetic, and electron microscopy evidence from Ancora, New Jersey, United States. Paleoceanography. https://doi. org/10.1029/2007pa001473

Lanci L, Kent DV (2006) Meteoric smoke fallout revealed by superparamagnetism in Greenland ice. Geophys Res Lett. https://doi. org/10.1029/2006gl026480

Li J, Pan Y, Chen G, Liu Q, Tian L, Lin W (2009) Magnetite magnetosome and fragmental chain formation of Magnetospirillum magneticum AMB-1: transmission electron microscopy and magnetic observations. Geophys J Int 177(1):33-42. https://doi.org/10.1111/j.1365-246X.2009.04043.x

Li J, Pan Y, Liu Q, Zhang K, Menguy N, Che R, Qin H, Lin W, Wu W, Peterson N, Yang X (2010) Biomineralization, crystallography and magnetic properties of bullet-shaped magnetite magnetosomes in giant rod magnetotactic bacteria. Earth Planet Sci Lett 293(3-4):368-376. https://doi.org/10.1016/j. epsl.2010.03.007

Li J, Ge K, Pan Y, Williams W, Liu Q, Qin H (2013) A strong angular dependence of magnetic properties of magnetosome chains: implications for rock magnetism and paleomagnetism. Geochem Geophys Geosyst 14(10):3887-3907. https://doi.org/10.1002/ggge.20228

Lin W, Bazylinski DA, Xiao T, Wu L, Pan Y (2014) Life with compass: diversity and biogeography of magnetotactic bacteria. Environ Microbiol 16(9):26462658. https://doi.org/10.1111/1462-2920.12313

Lin W, Paterson GA, Zhu Q, Wang Y, Zopylova E, Li Y, Knight R, Bazylinski DA, Zhu R, Kirschvink JL, Pan Y (2017) Origin of microbial biomineralization and magnetotaxis during the Archean. Proc Natl Acad Sci USA 114:2171-2176. https://doi.org/10.1073/pnas.1614654114

Liu Q, Torrent J, Morras H, Hong A, Jiang Z, Su Y (2010) Superparamagnetism of two modern soils from the northeastern Pampean region, Argentina and its paleoclimatic indications. Geophys J Int 183(2):695-705. https://doi. org/10.1111/j.1365-246X.2010.04786.X

Liu S, Deng C, Xiao J, Li J, Paterson GA, Chang L, Yi L, Qin H, Pan Y, Zhu R (2015) Insolation driven biomagnetic response to the Holocene Warm Period in semi-arid East Asia. Sci Rep. https://doi.org/10.1038/srep08001

Maher BA (2016) Palaeoclimatic records of the loess/palaeosol sequences of the Chinese Loess Plateau. Quatern Sci Rev 154:23-84

Mao X, Egli R, Petersen N, Hanzlik M, Zhao X (2014) Magnetotaxis and acquisition of detrital remanent magnetization by magnetotactic bacteria in natural sediment: first experimental results and theory. Geochem Geophys Geosyst 15(1):255-283. https://doi.org/10.1002/2013gc005034

Moskowitz BM, Frankel RB, Bazylinski DA (1993) Rock magnetic criteria for the detection of biogenic magnetite. Earth Planet Sci Lett 120(3-4):283-300. https://doi.org/10.1016/0012-821x(93)90245-5

Moskowitz BM, Frankel RB, Walton SA, Dickson DPE, Wong KKW, Douglas T, Mann S (1997) Determination of the preexponential frequency factor for superparamagnetic maghemite particles in magnetoferritin. J Geophys Res-Solid Earth 102(B10):22671-22680. https://doi.org/10.1029/97jb0 1698

Moskowitz BM, Bazylinski DA, Egli R, Frankel RB, Edwards KJ (2008) Magnetic properties of marine magnetotactic bacteria in a seasonally stratified coastal pond (Salt Pond, MA, USA). Geophys J Int 174(1):75-92. https:// doi.org/10.1111/j.1365-246X.2008.03789.x

Oldfield F, Thompson R, Dickson DPE (1981) Artificial magnetic enhancement of stream bedload — a hydrological application of superparamagnetism. Phys Earth Planet Inter 26(1-2):107-124. https://doi.org/10.1016/00319201(81)90103-5

Pan Y, Petersen N, Davila AF, Zhang L, Winklhofer M, Liu Q, Hanzlik M, Zhu R (2005a) The detection of bacterial magnetite in recent sediments of Lake Chiemsee (southern Germany). Earth Planet Sci Lett 232(1-2):109-123. https://doi.org/10.1016/j.epsl.2005.01.006

Pan Y, Petersen N, Winklhofer M, Davila AF, Liu Q, Frederichs T, Hanzlik M, Zhu R (2005b) Rock magnetic properties of uncultured magnetotactic bacteria. Earth Planet Sci Lett 237(3-4):311-325. https://doi.org/10.1016/j. epsl.2005.06.029

Petersen N, von Dobeneck T, Vali H (1986) Fossil bacterial magnetite in deepsea sediments from the South Atlantic Ocean. Nature 320:611-615

Prozorov R, Prozorov T, Mallapragada SK, Narasimhan B, Williams TJ, Bazylinski DA (2007) Magnetic irreversibility and the Verwey transition in nanocrystalline bacterial magnetite. Phys Rev. https://doi.org/10.1103/ physrevb.76.054406 
Roberts AP, Florindo F, Chang L, Heslop D, Jovane L, Larrasoana JC (2013) Magnetic properties of pelagic marine carbonates. Earth Sci Rev 127:111-139

Roch A, Muller RN, Gillis P (1999) Theory of proton relaxation induced by superparamagnetic particles. J Chem Phys 110(11):5403-5411. https:// doi.org/10.1063/1.478435

Schaefer R, Kehlbach R, Wiskirchen J, Bantleon R, Pintaske J, Brehm BR, Gerber A, Wolburg H, Claussen CD, Northoff H (2007) Transferrin receptor upregulation: in vitro labeling of rat mesenchymal stem cells with superparamagnetic iron oxide. Radiology 244(2):514-523. https://doi. org/10.1148/radiol.2442060599

Schuler D, Frankel RB (1999) Bacterial magnetosomes: microbiology, biomineralization and biotechnological applications. Appl Microbiol Biotechnol 52(4):464-473

Simmons SL, Edwards KJ (2007) Unexpected diversity in populations of the many-celled magnetotactic prokaryote. Environ Microbiol 9(1):206-215. https://doi.org/10.1111/j.1462-2920.2006.01129.x

Smirnov AV, Tarduno JA (2001) Estimating superparamagnetism in marine sediments with the time dependency of coercivity of remanence. J Geophys Res-Solid Earth 106(B8):16135-16143. https://doi.org/10.1029/2001j b000152

Tarduno JA (1995) Superparamagnetism and reduction diagenesis in pelagic sediments-enhancement or depletion. Geophys Res Lett 22(11):13371340. https://doi.org/10.1029/95gl00888

Tauxe L, Wu GP (1990) Normalized remanence in sediments of the western equatorial Pacific — relative paleointensity of the geomagnetic-field. J Geophys Res-Solid Earth Planets 95(B8):12337-12350. https://doi. org/10.1029/JB095iB08p12337

Tauxe L, Mullender TAT, Pick T (1996) Potbellies, wasp-waists, and superparamagnetism in magnetic hysteresis. J Geophys Res-Solid Earth 101(B1):571-583. https://doi.org/10.1029/95jb03041

Thorat ND, Lemine OM, Bohara RA, Omri K, El Mir L, Tofail SAM (2016) Superparamagnetic iron oxide nanocargoes for combined cancer thermotherapy and MRI applications. Phys Chem Chem Phys 18(31):21331-21339. https://doi.org/10.1039/c6cp03430f

Thorek DLJ, Chen A, Czupryna J, Tsourkas A (2006) Superparamagnetic iron oxide nanoparticle probes for molecular imaging. Ann Biomed Eng 34(1):23-38. https://doi.org/10.1007/s10439-005-9002-7

Tromsdorf UI, Bigall NC, Kaul M, Bruns OT, Nikolic MS, Mollwitz B, Sperling RA, Reimer R, Hohenberg H, Parak WJ, Förster S, Beisiegel U, Adam G, Weller H (2007) Size and surface effects on the MRI relaxivity of manganese ferrite nanoparticle contrast agents. Nano Lett 7(8):2422-2427. https://doi. org/10.1021/nl071099b

Ullrich S, Kube M, Schubbe S, Reinhardt R, Schüler D (2005) A hypervariable 130-kilobase genomic region of Magnetospirillum gryphiswaldense comprises a magnetosome island which undergoes frequent rearrangements during stationary growth. J Bacteriol 187:7176-7184

van de Moortele B, Reynard B, Rochette P, Jackson M, Beck P, Gillet P, McMillan PF, McCammon CA (2007) Shock-induced metallic iron nanoparticles in olivine-rich Martian meteorites. Earth Planet Sci Lett 262(1-2):37-49. https://doi.org/10.1016/j.epsl.2007.07.002

Walls MG, Cao C, Zhang KY, Li J, Che R, Pan Y (2013) Identification of ferrousferric $\mathrm{Fe}_{3} \mathrm{O}_{4}$ nanoparticles in recombinant human ferritin cages. Microsc Microanal 19(4):835-841. https://doi.org/10.1017/S1431927613001724

Wang YXJ, Hussain SM, Krestin GP (2001) Superparamagnetic iron oxide contrast agents: physicochemical characteristics and applications in MR imaging. Eur Radiol 11(11):2319-2331. https://doi.org/10.1007/s0033 00100908

Wang Y, Lin W, Li J, Zhang T, Li Y, Tian J, Gu L, Heyden Y, Pan Y (2015) Characterizing and optimizing magnetosome production of Magnetospirillum sp. XM-1 isolated from Xi'an City Moat, China. FEMS Microbiol Lett. https:// doi.org/10.1093/femsle/fnv167

Weiss BP, Kim SS, Kirschvink JL, Kopp RE, Sankaran M, Kobayashi A, Komeili A (2004) Ferromagnetic resonance and low-temperature magnetic tests for biogenic magnetite. Earth Planet Sci Lett 224(1-2):73-89. https://doi. org/10.1016/j.espl.2004.04.024

Worm HU, Jackson M (1999) The superparamagnetism of Yucca Mountain Tuff. J Geophys Rese-Solid Earth 104(B11):25415-25425. https://doi. org/10.1029/1999jb900285

Yamazaki T, Shimono T (2012) Abundant bacterial magnetite occurrence in oxic red clay. Geology 41(11):1191-1194. https://doi.org/10.1130/g3478 2.1

Yang C, Cao C, Cai Y, Xu H, Zhang T, Pan Y (2017) Effects of PEGylation on biomimetic synthesis of magnetoferritin nanoparticles. J Nanopart Res. https ://doi.org/10.1007/s11051-017-3805-y

Zhang T, Cao C, Tang X, Cai Y, Yang C, Pan Y (2017) Enhanced peroxidase activity and tumour tissue visualization by cobalt-doped magnetoferritin nanoparticles. Nanotechnology 28(4):045704. https://doi.org/10.1088/13616528/28/4/045704

Zhao X, Egli R, Gilder SA, Muller S (2016) Microbially assisted recording of the Earth's magnetic field in sediment. Nat Commun 7:10673. https://doi. org/10.1038/ncomms10673

Zhou K, Zhang W, Kui Y, Pan H, Zhang S, Zhang W, Yue H, Li Y, Xiao V, Wu L (2012) A novel genus of multicellular magnetotactic prokaryotes from the Yellow Sea. Environ Microbiol 14(2):405-413. https://doi.org/10.111 1/j.1462-2920.2011.02590.x

\section{Submit your manuscript to a SpringerOpen ${ }^{\odot}$ journal and benefit from:}

- Convenient online submission

- Rigorous peer review

- Open access: articles freely available online

- High visibility within the field

- Retaining the copyright to your article

Submit your next manuscript at $\boldsymbol{\nabla}$ springeropen.com 